\title{
Congenital Granular Cell Lesion: A Case Report
}

\author{
Dionline Borges Paulo1*, Bruna Rodrigues Barbosa1, Jerúsia Oliveira Ibiapina², \\ Ana Maria Gonçalves Rebelo², Teresinha Castello Branco Carvalho², \\ Lina Gomes dos Santos ${ }^{1,2}$ \\ ${ }^{1}$ Department of Specialty Medicine, Health Sciences Center, Federal University of Piauí, Teresina, Brazil \\ ${ }^{2}$ Department of Pathology, São Marcos Hospital, Teresina, Brazil \\ Email: *dionlineborges@hotmail.com
}

Received 28 August 2014; revised 27 September 2014; accepted 20 October 2014

Copyright (C) 2014 by authors and Scientific Research Publishing Inc.

This work is licensed under the Creative Commons Attribution International License (CC BY). http://creativecommons.org/licenses/by/4.0/

c) (i) Open Access

\begin{abstract}
The congenital granular cell lesion is a rare disease that affects newborns. We present a case of a patient with nodular lesions that were located on the anterior part of the maxillary alveolar. The surgical resection of the one lesion and its histological and immunohistochemical study were made.
\end{abstract}

\section{Keywords}

Congenital Epulis, Congenital Granular Cell Lesion, Surgery

\section{Introduction}

The neonatal oral pathologies are entities that due to its relatively low incidence, are sometimes unknown by the hospital staff responsible for the care of newborns. The anxiety of the family because of the appearance of the lesion makes the physician who is responsible for the diagnosis and treatment of these disorders have a major role in the proper management of these cases [1].

An example of neonatal oral disease is the congenital granular cell lesion (CGCL), it is also known as congenital epulis. This is a gingival congenital benign rare tumor whose evolution ceases after birth [2]. Therefore, it occurs exclusively in newborns babies [3]. It presents as a submucosal mass of varying size, usually single [4] but multiple cases have also been reported [5]. Its occurrence is sporadic and shows no familial tendency [6]. The CGCL occurs most frequently in the maxillary (maxillary/mandibular ratio: 3:1) especially in its anterior portion [7]. It presents preference for females (10:1), which suggests a hormonal factor involved in the devel-

"Corresponding author.

How to cite this paper: Paulo, D.B., Barbosa, B.R., Ibiapina, J.O., Rebelo, A.M.G., Carvalho, T.C.B. and dos Santos, L.G. (2014) Congenital Granular Cell Lesion: A Case Report. Case Reports in Clinical Medicine, 3, 566-569.

http://dx.doi.org/10.4236/crcm.2014.310123 
opment of the lesion [8]. The diagnosis is clinical and the recommended treatment is a surgical excision [4]. There are no reports of recurrence or malignant transformation [7]. This article describes a case of CGCL that was treated with surgical excision.

\section{Case Report}

EVNC, the female newborn was taken by her mother to the medical care due to the presence of gingival tumor. On physical examination, the patient had two nodular lesions that were located in the anterior part of the maxillary alveolar and with similar color to the adjacent mucosa (Figure 1). It was indicated the surgical biopsy of just one lesion.

The surgical specimen was then sent to the conventional histopathology study (Figure 2) and it showed that cell proliferation arranged in little tight nests with small, regular, monomorphic nuclei, abundant eosinophilic granular cytoplasm and they were permeated by blood vessels with thin walls. The immunohistochemical study showed positivity for vimentin, calretinin and CD68 (Figure 3) and negativity for pankeratins and S100 protein.

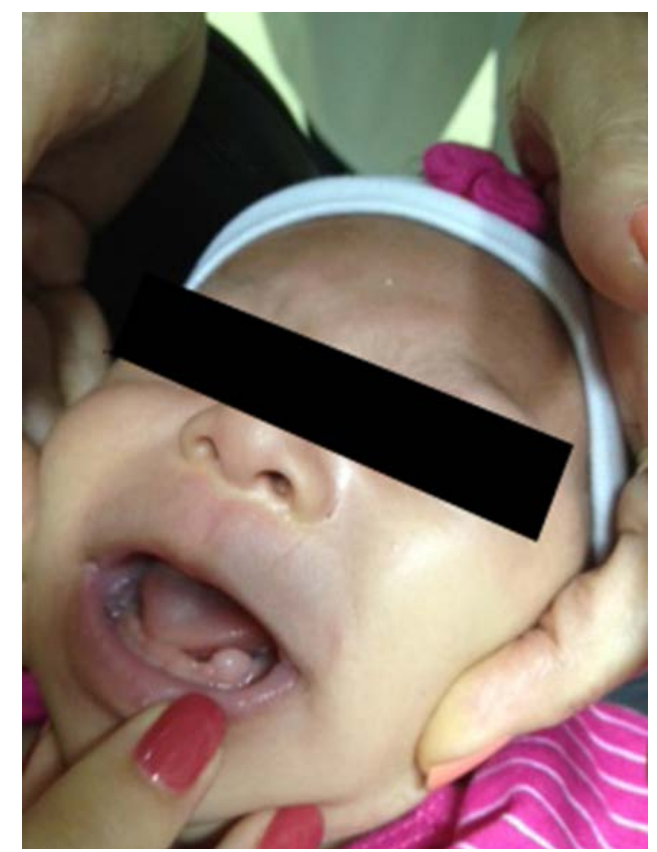

Figure 1. Clinical view of nodular lesion in the left gingival region.

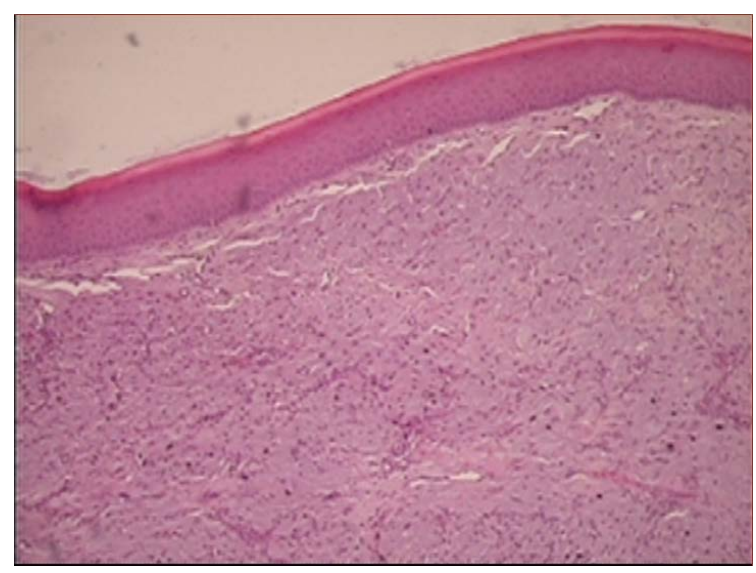

Figure 2. HE $100 \times$. Histopathologic view of congenital granular cell lesion. 

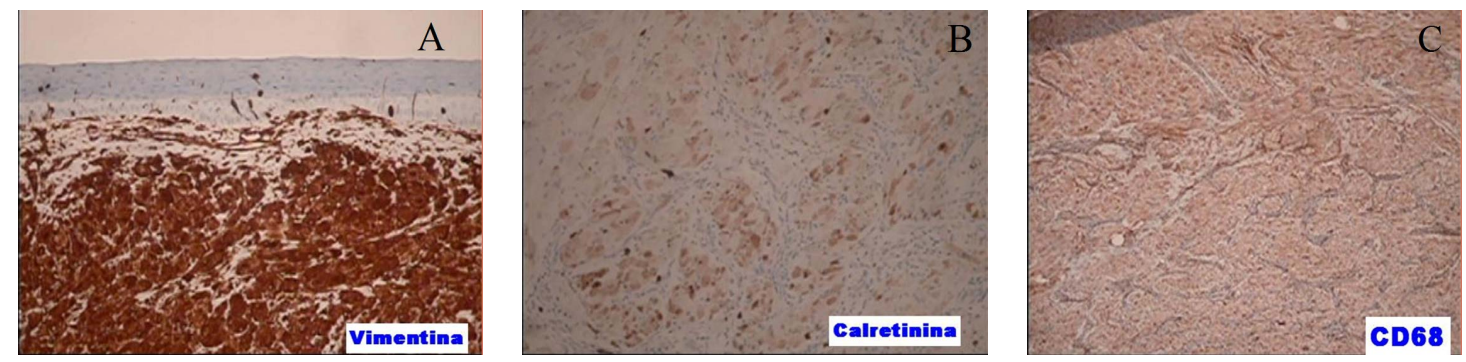

Figure 3. Immunohistochemical: vimentin (A), calretinin (B) and CD68 (C).

\section{Discussion}

In 1871, Neumann was the first to describe the injury he called congenital epulis or Neumann's tumor [7]. Currently, the World Health Organization appoints this tumor as congenital granular cell epulis [9]. However, according to Loyola et al., [7] the name congenital granular cell lesion (CGCL) seems to be the appropriate term due to the fact that it is not restricted to the maxillary alveolar, while the term epulis means the increase of the gingival volume [6].

The congenital granular cell lesion is seen in the neonatal period and it typically originates in gingival alveolar mucosa of the maxilla (2/3 of cases) [3]. However, it was also described as it is arisen from mandibular gingival mucosa, as well as at locations simultaneously. There are different tumor's sizes, from small millimeters to large tumors that it is $7.5 \mathrm{~cm}$, pedunculated, and it varies in color, from pink to raspberry red color [1]. Only $10 \%$ of the lesions are multiple and affect one or both edges. There are rare cases of concurrent diseases in the region alveolar and extra-alveolar [6], as well as cases of only one extra-alveolar lesion [9]. There is no involvement of the underlying bone tissue or unerupted deciduous teeth [6]. In spite of the controversies about the etiology of CGCL, authors in the literature are unanimous in affirming that it's a benign lesion [4] [7]. Reports of spontaneous regression corroborate innocuous behavior of this disease [7], and the recurrence is not observed even after incomplete excision [4] [6]. In this case, there was only resection of one lesion.

There are several theories about the origin histological: myoblastic [4] [7], neuroblastic, odontoblast, fibroblastic or histiocytic [4] [6] [7]. The most widely accepted hypothesis is the degenerative process of one of undifferentiated mesenchymal cells which, in turn, are capable of multiple differentiation [7] [9]. The diagnosis is made by the conventional histopathological examination, which shows round cells with abundant granular eosinophilic cytoplasm and round to ovoid nuclei lightly basophilic findings as seen in this case. There are neither mitoses nor cross striations, but the capillaries are abundant. The immunohistochemical that was found confirmed the mesenchymal origin [1].

The differential diagnosis should be done primarily with hemangioma, lymphangioma, fibroma and rhabdomyosarcoma [10]. The granular cell tumors or myoblastoma granular cell should also be cited as a differential diagnosis because they have similar histological appearance [11]. Their differences are the presence of a thin layer between the vascular granular [6] cells and the absence of superficial epithelial hyperplasia pseudoepitheliomatous in cases of CGCL [4]. Additionally, immunohistochemical studies shows expression of the S100 protein [4] [6] [7] [9], the $75 \mathrm{Kd}$ growth factor receptors, trk gene [7] [9] and phosphotyrosine-positive cells [7] in the granular cell tumors and the absence of these markers in CGCL. There are also differences between the clinical presentation and the epidemiology. The CGCL is present at birth which does not occur with granular cell tumor, because it can occur at any age. The granular cell tumor is most commonly located on the tongue, but may also occur in other parts of the body [9].

The neonatal disease may be perceived before birth, on examination of prenatal care, such as ultrasound [12]. When there is risk of airway obstruction at birth, a multidisciplinary action previously planned, with the presence of neonatologist, anesthesiologist and otolaryngologist doctors, it may allow the resolution of the case even during labor, what constitutes the so-called perinatal treatment [13]. Thus, due to the harmless nature of CGCL, some authors do not recommend surgical excision, they say that small lesions tend to regress and disappear spontaneously. Then, they indicate excision when there is difficulty in breathing or feeding of the newborn [7] as in the case described here. However, some other authors recommend simple surgical excision or $\mathrm{CO}_{2}$ laser treatment, after that the tumor is observed [10]. 


\section{Conclusion}

The clinical knowledge about congenital granular cell lesion is of interest to the pediatrician, gynaecologist, neonatologist, otolaryngologist, pathologist and maxillofacial surgeon. Because it is a rare entity, a multidisciplinary approach in the efficient management of such cases improves the diagnosis and the appropriate treatment.

\section{References}

[1] Azevedo, R.A., Galli, G.B., Pereira, C.L. and Pires, M.S.M. (2005) Epúlide Congênita. RGO, Porto Alegre, 53, 206209.

[2] Chami, R.G. and Wang, H.S. (1986) Large Congenital Epulis of Newborn. Journal of Pediatric Surgery, 21, $929-930$. http://dx.doi.org/10.1016/S0022-3468(86)80091-4

[3] Menéndy, O.R. (1989) Estomatologia Pediátrica. In: Tommasi, A.F., Ed., Diagnóstico em Patologia Bucal, Vol. 2, Pancast Editorial, São Paulo, 559-586.

[4] McGuire, T.P., Gomes, P.P., Freilich, M.M. and Sándor, G.K. (2006) Congenital Epulis: A Surprise in the Neonate. Journal of the Canadian Dental Association, 72, 747-750.

[5] Yavuzer, R., Ataoglu, O. and Sari, A. (2001) Multiple Congenital Epulis of the Alveolar Ridge and Tongue. Annals of Plastic Surgery, 47, 199-202. http://dx.doi.org/10.1097/00000637-200108000-00017

[6] Godra, A., D’Cruz, C.A., Labat, M.F. and Isaacson, G. (2004) Pathologic Quiz Case: A Newborn with a Midline Buccal Mucosa Mass. Congenital Gingival Granular Cell Tumor (Congenital Epulis). Archives of Pathology Laboratory Medicine, 28, 585-586.

[7] Loyola, A.M., Gatti, A.F., Pinto, D.S. and Mesquita, R.A. (1997) Alveolar and Extra-Alveolar Granular Cell Lesions of the Newborn: Report of Case and Review of Literature. Oral Surgery, Oral Medicine, Oral Pathology, Oral Radiology, and Endodontics, 84, 668-671. http://dx.doi.org/10.1016/S1079-2104(97)90370-X

[8] Silva, G.C.C., Vieira, T.C., Vieira, J.C., Martins, C.R. and Silva, E.C. (2007) Congenital Granular Cell Tumor (Congenital Epulis): A Lesion of Multidisciplinary Interest. Medicina Oral Patologia Oral y Cirugia Bucal, 12, 428-430.

[9] Senoo, H., Iida, S., Kishino, M., Namba, N., Aikawa, T. and Kogo, M. (2007) Solitary Congenital Granular Cell Lesion of the Tongue. Oral Surgery, Oral Medicine, Oral Pathology, Oral Radiology, and Endodontics, 104, 45-48. http://dx.doi.org/10.1016/j.tripleo.2007.01.038

[10] Lopez-Lacalle, J.M., Aguirre, I., Irizabal, J.C. and Nogues, A. (2001) Congenital Epulis: Prenatal Diagnosis by Ultrasound. Pediatric Radiology, 31, 453-454. http://dx.doi.org/10.1007/s002470000416

[11] Tucker, M.C. (1990) Gingival Granular Cell Tumors of the Newborn. An Ultrastructural and Immunohistochemical Study. Archives of Pathology Laboratory Medicine, 114, 895-898.

[12] Charrier, J.B. (2003) Obstructive Congenital Gingival Granular Cell Tumor. Annals of Otology, Rhinology Laryngology, 112, 388-391.

[13] Kumar, P. (2002) Obstructive Congenital Epulis: Prenatal Diagnosis and Perinatal Management. Laryngoscope, 112, 1935-1939. http://dx.doi.org/10.1097/00005537-200211000-00005 
Scientific Research Publishing (SCIRP) is one of the largest Open Access journal publishers. It is currently publishing more than 200 open access, online, peer-reviewed journals covering a wide range of academic disciplines. SCIRP serves the worldwide academic communities and contributes to the progress and application of science with its publication.

Other selected journals from SCIRP are listed as below. Submit your manuscript to us via either submit@scirp.org or Online Submission Portal.
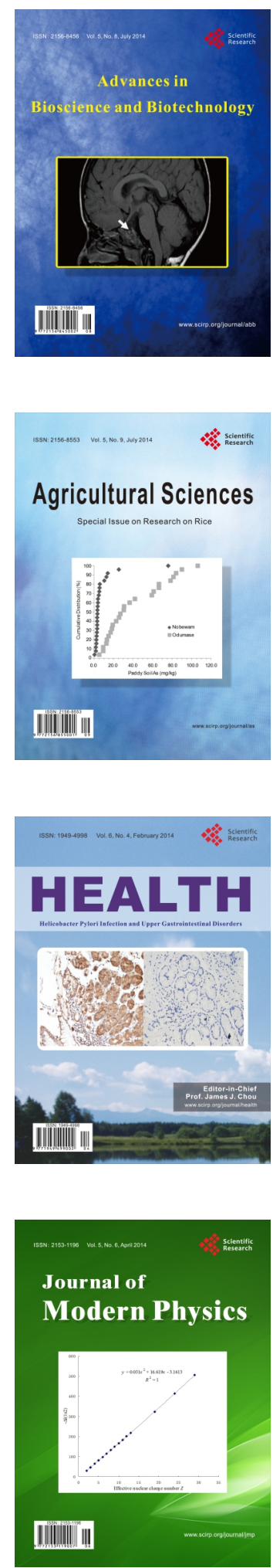
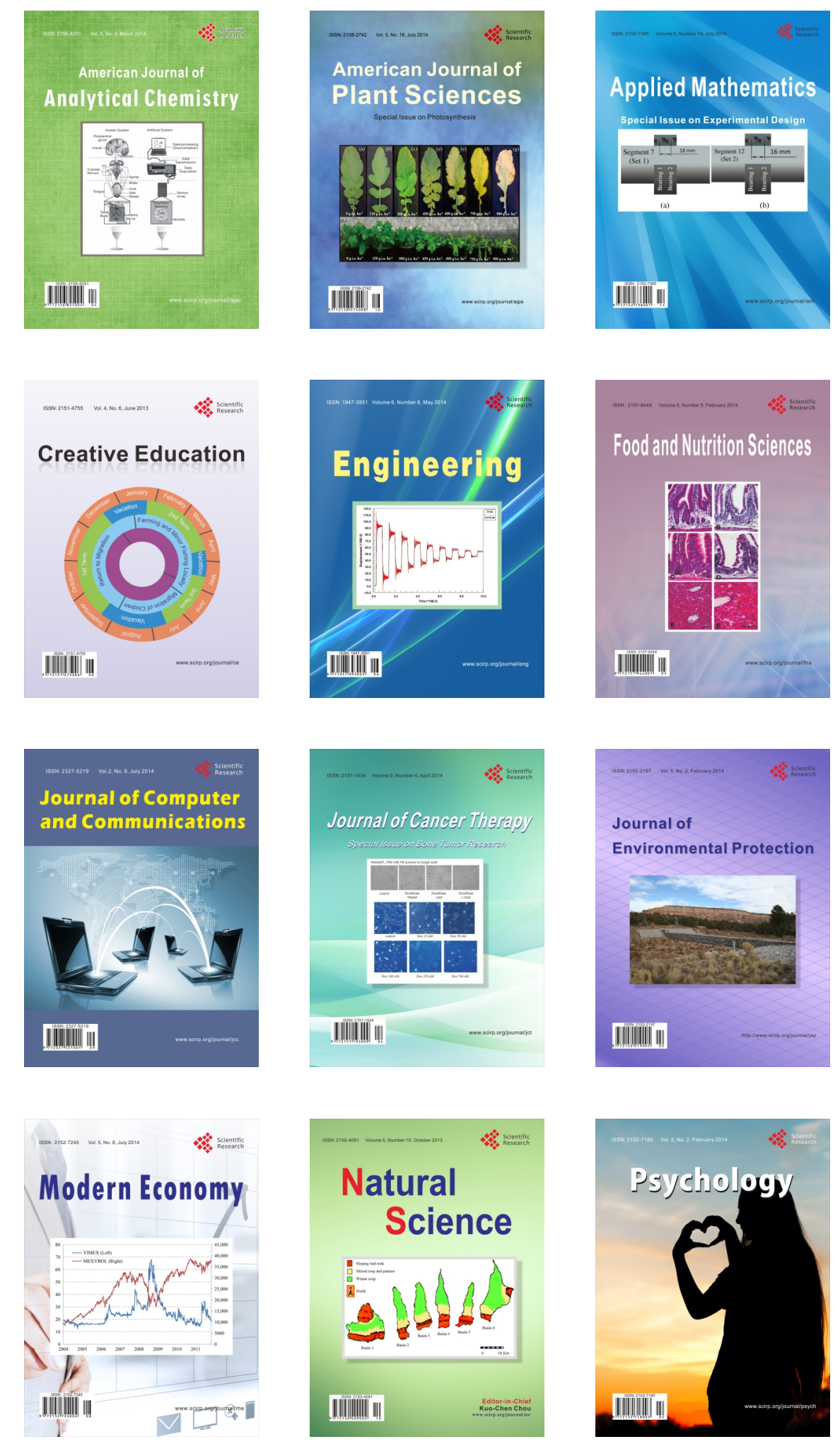